Article

\title{
The Social Democrats of Scholarship: Austrian Imperial Peripheries and the Making of a Progressive Science of Nationality, 1885-1903
}

\section{Thomas R. Prendergast}

Department of History, Duke University, Durham, NC 27705, USA; E-Mail: trp14@duke.edu Academic Editor: Malachi Hacohen

Received: 14 September 2015 / Accepted: 25 September 2015 / Published: 21 October 2015

\begin{abstract}
To what extent and in what ways did the intellectual climate of Austria's often ethnolinguistically heterogeneous borderlands contribute to the formation, institutionalization and diffusion of emerging social scientific discourses during the final decades of the 19th century? Investigating the intellectual exchange between two early proponents of folklore studies (Volkskunde) — the Slavonian-German-Jewish Friedrich Salomon Krauss (1859-1938) and Bukovinian-German Raimund Friedrich Kaindl (1866-1930) - this paper argues that imperial peripheries, while traditionally overlooked as sites of knowledge production, in fact played a pivotal role in the development of an important brand of "progressive" social scientific research, one defined by a critical stance toward the prevailing historicist paradigms of the time. These self-described "social democrats of scholarship" collaborated, both formally and informally, on a number of related theoretical projects aimed at disrupting the exclusionary narratives of the academic establishment and re-focusing scholarly attention on the sociological, rather than historical, character of ethnonational difference. In this way, the nationalities question spurred, both in the center and at the margins of the monarchy, the development of new sciences of nationality intended to sustain Austria's imperial structure.
\end{abstract}

Keywords: empire; Jews; socialism; peripheries; Austria; folklore; Krauss; Kaindl

In an 1893 edition of Am Ur-Quell. Monatsschrift für Volkskunde ("At the Fountainhead: A Monthly for Folklore"), Friedrich Salomon Krauss, the journal's Slavonian-born, German-speaking Jewish editor, described the state of folklore studies (Volkskunde) as follows: 
Let us not surrender to self-delusion, but rather openly and frankly admit the fact that folklore is today in Europe still one of the most unpopular and least recognized sciences [Wissenschaften]....Ethnologists [Volksforscher] are so to speak the Social Democrats of scholarship. They are the newcomers, the subversives, the skeptics, the know-it-alls. They hold scholastic "historical criticism" in contempt and, as natural scientists, have the effrontery to study humans in the way that once only the animal world was observed and described ([1], p. 151).

Exactly a decade later, in 1903, the Czernowitz historian, folklorist, and later Pan-German ideologue, Raimund Friedrich Kaindl approvingly reproduced, word for word, Krauss's striking appraisal in his 1903 introduction to the discipline, calling his comments "very appropriate as a characterization of the position of the field at the time" ([2], p. 44). In the same text, Kaindl went on to cite the controversial Jewish folklorist several more times; in fact, in key respects, the methodology laid out in the book was heavily indebted to Krauss. Such a strange and evocative remark on the part of Krauss, and its later citation in the work of a German nationalist, raises the question: in what sense were the scholarly objectives of the nascent field of folklore (Volkskunde) understood to be analogous to the political objectives of the Social Democrats, and why did these perceived political affinities appeal to such an otherwise radically intellectually and politically dissimilar pair of thinkers?

In this paper, I will attempt to clarify the meaning of this seemingly incongruous comparison. Turning away from high political history and toward the nascent field of national folklore offered, I argue, a wide variety of actors a political language with which to contest the increasingly strident tone of national activists and to affirm and secure, rather than criticize, Austria's supranational, imperial structure. With its emphasis on the social and economic realities of the present, folklore complicated and de-mythologized the political historian's exclusionary claims to national continuity and homogeneity, thereby allowing minority populations the possibility of re-inserting themselves into the political imaginary of their respective regions. Despite varying degrees of attachment to the Pan-German project-Krauss remained committed to a traditional liberal vision of a German-led Central Europe, while Kaindl increasingly embraced an ethnic notion of Germanness and German solidarity — both Krauss and Kaindl, like Otto Bauer and the Austromarxists, managed to blend (German) nationalism and pro-imperialism in a single methodological and theoretical agenda.

By situating theories of culture being produced and circulated by these two early Austrian folklorists in the context of late imperial political movements, I hope to draw attention to the intimate relationship between national minority activism, emerging social science discourses, and the question of imperial loyalties, in the process both broadening our picture of late imperial progressive cultural politics and sharpening our understand of its specific motivations and objectives. Ultimately, Krauss and Kaindl's affinity to one another and to a particular methodological paradigm reveals at least three important, and up to this point, largely neglected, aspects of turn-of-the-century Austrian intellectual life. First, their groundbreaking contributions to the field of folkloristics testify to the critical self-reflexivity and creativity of late imperial Austrian social science. Rather than simply import and modify German, French, and British ideas about "nationality" and "race," scholars in this region often criticized and revised prevailing conceptions of ethnonational difference; in fact, some, such as Krauss, developed entirely novel conceptual frameworks. Second, their exchange suggests that strategic 
collaborations between minority populations, particularly Jews and ethnic Germans, took the form not only of political alliances, as Gary Cohen has shown in the case of Prague, but also common intellectual projects, such as a pro-imperial method of folklore research [3]. Third, while folklore as an individual discipline failed, in the end, to overcome the romantic idealism to which it had set itself in opposition, the larger anti-establishment and, in a certain sense, "progressive" academic discourse of which it formed a part emerged, as we will see, out of conversations taking place not in the imperial capital of Vienna, but rather on and between the peripheries of the monarchy.

Scholars working in folklore during the final two decades of the 19th century tended to give nearly identical evaluations of the state of their field. Between 1880 and 1900, narratives much like the one reproduced above were published in the monarchy's leading ethnological journals on an almost annual basis. That Volkskunde found itself on the margins of Austrian academia, and was looked upon by the more established disciplines of anthropology and history with suspicion and skepticism, was, it seems, a major rhetorical commonplace among leading figures in the field. In an 1893 volume of Anton Hermann's Ethnologische Mitteilungen aus Ungarn (Ethnological Notices from Hungary), the Hungarian folklorist Ludwig von Katona described Volkskunde as a classic example of a "new branch of science forced to fight for its existence" and assert its independence from existing disciplines ([4], p. 43). Anton Herrmann, the journal's editor-in-chief, similarly bemoaned the discipline's lack of public prestige. Commenting on the state of the field in Hungary, Herrmann flatly declared in 1896: "our statesmen still display in general little understanding of the political significance of ethnography." ([5], p. 5). Even ten years later, Kaindl, the historian-turned-folklorist, wrote the following: "folklore is a very young science for which there is very little understanding, and for this reason, it has not found its due recognition." ([2], p. 41). Folklorists, he commented, were until recently "seen as ridiculous people." [2].

The frequency with which this story was told leaves little doubt that the discipline was characterized during the final two decades of the 19th century by both a deep sense of discomfiture and an air of missionary self-confidence. In the eyes of the academic establishment, folklorists were not genuine scholars, but rather bohemians, dilettantes, aesthetes, and, more figuratively, according to Krauss and Kaindl, "social democrats." What exactly was the basis for this comparison? Upon a first reading, the connection Krauss draws between the increasing popularity of folklore research and the growing appeal of the social democratic party may represent little more than a simple rhetorical flourish, an intentionally provocative addition to what was, as we have seen, an otherwise rather typical description of the field. This may be true to a certain extent. But the fact that Krauss made this pronouncement in the context of a more serious discussion of "scholastic historical critique" and the natural scientific method indicates that the comparison was, at least in some significant sense, earnestly meant. Furthermore, Kaindl's approving citation of this passage in his later introduction to the field of Volkskunde suggests that certain contemporary scholars considered the comparison particularly apt.

For both Krauss and Kaindl, Volkskunde's poor standing within the Austrian scholarly community, as well as its recent rise to public prominence, could be traced back to a common intellectual trend: the re-appraisal of academic history and its political commitments. If, as both writers at the time frequently remarked and contemporary historians continue to argue today, the historical discipline fell in the second half of the 19th century into the hands of a recklessly patriotic and chauvinistic elite, 
then Volkskunde emerged as a kind of anti-establishment countermovement, a progressive response to the historicist idealism on which the grand political claims of many scholars were being based ([6], p. 325). As both practitioners and, more importantly, theorists of folkloristic methods, Krauss and Kaindl spearheaded these developments, contributing in different, though equally important ways, to the creation of a new and politically subversive conceptual framework.

Born into an observant Jewish family in 1859 in Požega, Slavonia, Krauss matured to adulthood in a physical and intellectual space characterized by the increasingly contentious conflict between rival nationalist political visions; while he identified as German, he nevertheless felt a deep sense of loyalty to his Croatian-Slavonian homeland, as well as to the empire's Jewish community [7]. This complex sense of belonging rendered him especially attentive to, and critical of, the exclusionary rhetoric being adopted in the final two decades of the century by both Croatian and German nationalists. Krauss sounded the battle cry against history's nationalist entanglements as early as 1885 . In the introduction to his second published monograph, Sitte und Brauch der Südslaven, Krauss openly confessed to his unsympathetic view of historically oriented folklore research:

The difference between me and them, that is, my predecessors, the South Slav professional historians, consists solely in the fact that they, in full faith, present the past as if they had personally been there, while I am by nature a heretic in these matters. The early history of the South Slavs is not my history ([8], p. VIII).

Rather than comb, as historians typically did, through the traditional documents of political history - "the moldy manuscripts of gospel translations and the statutes of different municipalities and petty duchies"-Krauss intended to study and describe his subjects from the standpoint of the present, to paint a realistic picture of their lived experience ([8], p. VII). His mission was, as he saw it, to "record and faithfully present what has been lived through and felt" ([8], p. VII). He reiterated this basic commitment to the study of presently existing cultures, and skepticism toward political historical claims, in both published essays and private correspondences. In his mind, the advantages of the cultural approach were clear:

Declaring, for example, the general concordance of humanity's social structures and perceptions to be the product of a unified tradition or blood relationship or common political history leaves one clinging to faulty evidence and empty conjectures, and explains nothing for certain. But, on the other hand, if one grasps the general predispositions of man, wherever he appears, and his capacity to adapt himself to his surroundings, then the difficulty involved in understanding what exists [das Vorhandene] and what has come into being [das Gewordene] disappears ([9], pp. 64-65).

Not everyone, however, agreed with Krauss on the wisdom of his approach. The academy's unsympathetic, sometimes openly hostile view of folkloristic and otherwise unorthodox methodologies represented a major obstacle to Krauss's professional advancement. In 1887, his petition to habilitate at the Philosophical Faculty of the University of Vienna was unanimously rejected; according to Krauss, this was because, in the faculty's opinion, "old wives' tales and beggar songs," the stuff of folklore research, "did not count as scholarship [Wissenschaft]" ([9], p. 48). He also raised the ire of the established scholars of the Anthropologische Gesellschaft (Anthropological Society) in Vienna, 
where Krauss had for several years served as a junior fellow. The Society, founded in 1870 and tasked, inter alia, with collecting comprehensive ethnographic data on the monarchy's various nationalities, appears to have lost patience with Krauss's iconoclastic style, eventually forcing him to quit his research post in 1889 ([9], p. 49; [10], pp. 59-60).

Following his dismissal, Krauss's writing grew even more combative in tone. In his third book on South Slav folklore, Volksglaube und religiöser Brauch der Südslaven (1890), Krauss mounted a ferocious critique of prevailing historical methods and proposed a set of new guidelines for the practice of ethnographic research. Explicitly taking aim at the work of Natko Nodilo (1834-1912), Professor of Croatian and Serbian History at the University of Zagreb, Krauss denounced his colleague's work as fanciful "Tendenzschriftstellerei," slanted or biased writing ([11], p. VIII). Older and more professionally connected than Krauss, Nodilo had, with financial support from the Croatian Academy of Sciences, published several influential monographs devoted to the topic of medieval Croatian and Serbian history. In Krauss's mind, Nodilo's work amounted to nothing more than a "cluster of implausible fantasies and dissolute reveries," and was entirely "worthless" as a work of science ([11], p. XI). True folklorists, he chided him, "seek, in constant touch with real, rather than poetically constructed, historical events, and in accordance with the position granted to us by empirical psychology, to understand and become familiar with the history of religion's real factors" ([11], p. VIII). Three years later, Krauss published a biting satire of the work of another well-respected scholar of South Slav folklore, Gregor Krek (1840-1905). This book-Böhmische Korallen aus der Götterwelt ("Trumperies from the World of the Gods," 1893) — consisted of a sort of catalogue of the various willful self-deceptions to which his colleague had, he believed, abandoned himself, followed by a direct, extended, and highly sarcastic censure of the methodology employed by the Graz professor in his Einleitung in die slavische Literaturegeschichte ("Introduction to Slavic Literary History," 1887) $[12,13]$.

Examining the logic which underlay the formation of national identities, what he referred to in other works as the "international quality of nations" ("das Internationale der Nationen"), was Krauss's primary goal, not the legitimation of historical claims to territory or the confirmation of claims to national homogeneity ([14], p. 172). As he opined in an issue of the Zeitschrift für deutsche Volkskunde ("Journal for German Folklore"): "Folklore is only in special cases national, but by nature humanistic in its research results. This is the touchstone for its scientific quality" ([9], p. 64). If folklore had anything to contribute to the cause of national self-improvement, it was, paradoxically enough, the self-critical study of nationality. Ever loyal to the emperor, he concluded his contribution to the famous Länder Österreich-Ungarns in Wort und Bild ("Lands of Austria-Hungary in Word and Image") series, Die vereinigten Königreiche Kroatien und Slavonien ("The United Kingdoms of Croatia and Slavonia"), with an admonishment to popular education:

Not Croatian politics, but rather popular education will determine the future of Croatia and Slavonia. May it be said to my fellow countrymen: not your politics and grandstanding (Großrednerei), but hard work and education will make you free, the one prerequisite being: loyalty to King and Empire! (König und Reich) ([9], p. 64; [15]).

Folklore's great appeal lay, he believed, in its special ability to undercut the romantic political pretensions of academic historicism, to fragment its idealistic and linear tales of national continuity 
and homogeneity. For him, a rigorous commitment to scientific objectivity went hand in hand with loyalty to the emperor and skepticism toward the nationalist self-flattery in which many scholars at the time were engaged.

Raimund Friedrich Kaindl, born to German-speaking parents in Czernowitz in 1866, found himself in a situation in many ways comparable to that of Krauss. An extra-ordinary and then, beginning in 1905, ordinary professor at the German-language Franz-Josephs-Universität in Czernowitz, Kaindl perceived the place of Germans in this far-flung part of the empire to be under siege by Romanian and Ukrainian nationalists, armed, as he saw it, with the ideological weapons provided to them by a certain class of political historians [16]. Folklore promised a means of countering these developments, a way of looking at the world which could both deflate nationalist-legitimationist historical claims and bolster his fellow Bukovinian Germans' sense of local belonging. Kaindl's 1903 introduction to folklore, Die Volkskunde: ihre Bedeutung, ihre Ziele und ihre Methode ("Folklore: its Significance, its Goals, and its Method"), was written "with special attention to folklore's relationship to historical scholarship," and reads in many ways like a Kraussian critique of traditional history writing. In his attempt to make a case for the usefulness, and more importantly, the ethical superiority of folklore studies and other recent methodological innovations in the broader field of Kulturgeschichte ("Cultural History"), he asks his readers the following series of rhetorical questions:

...is it not extremely one-sided (einseitig), that we learn about knightly accolades and ceremonies of the imperial coronation in as much detail as is possible, but nothing about similar precursors in the life of the people (Volksleben), which must in fact have been the basis for these things? Is it all well and good that we are taught in great detail about the isolated doings of extraordinary men or...a particular art movement, and know nothing about the nature of popular art, and in fact are hardly aware that such a thing even exists? ([2], p. 54).

There has been, he goes on to argue, a kind of "democratic" turn in Austrian academia, a shift away from the lofty dynastic chronicles of previous generations and toward the popular cultural histories of a dawning mass-political age. The growing prestige of Volkskunde, which Kaindl views as an indispensible part of this democratizing movement, marks in this respect a sea change in Austrian intellectual life:

Instead of the mere narration of political events, of wars and peace accords, we are beginning to pay greater attention to the work [Arbeit] of the people and its development. If in earlier historical writing the heads and leading classes of the state played the primary role, now the popular masses, their lives, strivings and actions are starting to attract more notice. It is, so to say, in the air at the moment ([2], pp. 53-54).

Whereas history tells the story of the elite, of kings, queens, ministers, and parliamentarians, Volkskunde - the localized study of national traditions and customs-lends a voice and an academic vocabulary to the "popular masses," in his case, primarily, but not, at this point, exclusively, the "Carpathian German" masses to which he belonged [17]. One of Kaindl's aims in re-focusing the historian's gaze on folk culture was, of course, to legitimize the study of his "besieged" German "Volk," but this objective was to be reached indirectly, through a project of comparative ethnography. 
By turning an ethnographic eye to Austria's constituent peoples, folklore promised to uncover a "principle of development [Entwicklungsprinzip] deeper than that of nationality [Nationalität]"-the logic of national difference ([2], p. 33). An appreciation of the cosmopolitan, he held, went hand in hand with an appreciation of the national. Given the state of the Nationalitätenfrage ("Nationalities Question") in the monarchy, the public dissemination of ethnography had become, he was convinced, a matter of urgent political necessity_ "there is," he declared, "hardly any other territory [Gebiet] that could gain such salubrious profit from folkloristic research" ([2], p. 47).

A method wedded to the affirmation of the Austrian state was not, however, the only thing Kaindl shared in common with Krauss. The author approvingly cited not only Krauss's critique of the historical school of folklore research and call for a more socioculturally oriented methodology, but also Krauss's objection to the then prevalent distinction between so-called Natur- and Kulturvölker, as well as his understanding of Volkskunde's potential for valuable contributions to imperial policymaking ([2], pp. 50, 81). Most revealing of all, he explicitly cites Krauss and his highly divisive Böhmische Korallen in a discussion aimed at warning his readers of folklore's potential for political manipulation and abuse ([2], pp. 90, 117, 128). Given Krauss's marginal position within Austrian academics and the provocative, highly unorthodox nature of his methodology, Kaindl's decision to base his introduction to Volkskunde on the work of his Slavonian-German-Jewish colleague is noteworthy. At the time (1903), several other general introductions to Volkskunde were available in Central Europe; his heavy reliance on Krauss's theoretical writings, therefore, cannot be attributed to a simple lack of alternative scholarly literature on the subject (cf. [18-21]). While muted in its praise, Kaindl's book clearly took a side in the ongoing debate between Krauss and more established folklorists. If not an outright endorsement, the book nonetheless displayed a great deal of sympathy for Krauss's program ([9], p. 59).

With this common opposition to academic historicism in mind, we can begin to interpret Krauss and Kaindl's somewhat cryptic invocation of "social democracy." In a certain sense, their decision to appropriate for themselves this surprising descriptor speaks to the special conditions under which Volkskunde developed. Around the turn of the 20th century, historicist theories of culture and social development remained deeply entrenched in the Central European academy, not only among historians, but also among economists, literary critics, and those scholars working in the still amorphous field of Volkskunde and Volkswissenschaft (cf. [22,23]). Rigid stadial schemata, which posited a linear evolution of cultures and a hierarchy of natural and historical peoples, formed the basis of most studies of literature, language, art history and political history, and even, as several scholars have shown, entered into the consciousness of the non-scholarly community by way of mass-market scientific literature, popular exhibitions and public art (cf. [24,25]. Yet, at the same time, folklorists lacked a common platform for the discussion of the discipline's methods, topics of analysis, and research objectives. The Zeitschrift für österreichische Volkskunde ("Journal for Austrian Folklore") - Cisleithania's first journal specifically dedicated to Volkskunde — only began publication in 1895, and was closely linked, both personally and in terms of academic mission, to the above-mentioned Anthropologische Gesellschaft in Vienna. There were relatively few institutionalized opportunities for engagement with folkloristic research, and the boundaries between different fields of study remained indistinct and easily traversable. 
Given this institutional and disciplinary fluidity, Krauss and Kaindl's exchange should be seen as part of a larger, transdisciplinary trend in the social sciences, rather than a single, isolated occurrence. One such trend was the turn away from historical understandings of nationality toward a "sociology" of national belonging. In a certain sense, the folklorists' intellectual and political project resembled that of Otto Bauer and the Austromarxists, who refused - much to the chagrin of orthodox Marxists - to ignore the central importance of the nation as a real, existing social entity. Though admittedly articulated in a less systematic manner, Krauss and Kaindl's methodology for Volkskunde was undergirded by many of the same principles to which Bauer subscribed. Both would agree, with qualifications, of course, with the critique of nationalist discourse mounted in Bauer's classic Die Nationalitätenfrage und Sozialdemokratie ("The Nationalities Question and Social Democracy," 1907):

...The national character has been unjustly attributed a continuity that can be historically refuted... A community of character links the members of a nation together in a particular era, but it by no means links the nation of our era with its ancestors of two or three thousand years ago ([26], pp. 20-21).

Like Krauss and Kaindl, Bauer sought to reform the writing of history. Bauer's 1911 Geschichte Österreichs, a short introduction to Austrian history designed for students of Arbeiterschulen ("Workers' Schools"), sets up a nearly identical contrast between the "old" and "new" modes of Geschichtsauffassung ("Conceiving of History"):

Our familiarity with Austrian history comes from elementary school (die Volksschule). It tells us about aristocrats, statesmen and field marshals, about marriages, wills, and battles. The future of the state and of its peoples appears to be dependent on the talent, good will and luck of a few dominant people (Herrscher) ([27], p. 4).

This new kind of history, he goes on to report, was distinguished by its uncompromisingly materialistic approach to the past. Of course, the fact that the leading theorist of Austrian Social Democracy would endorse a Marxist conception of history is hardly surprising. What is more interesting, and revealing, is the title Bauer recommends in this same book under the category of "bourgeois depictions of Austrian History," the third edition of Franz Martin Mayer's Geschichte Österreichs, mit besonderer Rücksicht auf das Kulturleben ("The History of Austria, with Special Reference to Cultural Life") ([27], p. 5; [28]). First published in 1874 and subsequently thoroughly revised in 1900 and 1909, Mayer's Geschichte, as the title suggests, was written as a work of cultural, not political, history. In the introduction to the second edition, he warns his readers:

My book is not written for those who are of the opinion that historical writing should only deal with wars and peace treaties; for the focus of my work lies in the presentation of the work of the people, in the development of its culture ([28], pp. V-VI).

Following Mayer's death in 1914, Kaindl, to bring the story full circle, would serve as the editor of a fourth, revised edition of Geschichte Österreichs. This new edition, entitled Geschichte und Kulturleben Deutschösterreichs ("History and Cultural Life of German Austria"), subtly endorsed the idea of a kind of German-led Donauföderation ("Danubian Federation"), an unpopular stance for which he came under a firestorm of criticism from both Pan-Germanists and Catholic conservatives [29]. 
There was, then, an odd sort of convergence between the academic agendas of a wide variety of thinkers from across the political spectrum. While Krauss and Kaindl were of course not advocating for the same sort of left-wing political project as Bauer, one can certainly detect a common interest in the link between the Nationalitätenfrage in Austria-Hungary and prevailing methods of historical scholarship. To deny Austria's various peoples a place within the cultural imaginary of the state, to ignore the everyday life of the "masses" and insist upon traditional imperial legal history would, they all agreed, only lead to further instability; at the same time, they also realized that this turn toward "the people" and their customs threatened to exacerbate existing tensions, particularly in its romantic, essentializing form. Their solution was to forge a kind of middle course. Unlike the supranational Reichsgeschichte ("imperial history") of Josef Halfert and Hans von Voltelini, which, by focusing on legal history, aimed to suppress national histories, Volkskunde embraced national differences as the subject of cultural-historical research, not, at least at first, in the name of nationalist agendas, but rather for the supposed good of the imperial state (cf. [30,31]). By insisting upon the study of Austria's nationalities not as historically continuous political entities, but rather as presently existing cultural communities, Krauss and Kaindl, like their Social Democratic counterparts, hoped to rein in nationalism's centrifugal and exclusionary tendencies.

The Slavonian-Jewish Krauss and the Bukovinian-German Kaindl saw in this new field a potentially powerful tool with which to deflate the ballooning pretensions of nationalist movements, and shared, at least in this early phase of their careers, both a sympathy to the cause of German nationalism and a commitment to the integrity of the Austrian imperial structure. Perceiving themselves to be under threat from the same set of intellectual developments, they endeavored to articulate a suitable response, formulating separate, though at first frequently intersecting methodological counter-projects. Yet, despite their common sympathies, and despite their in many ways comparable political situations vis-à-vis local majority nations, Krauss and Kaindl nonetheless conceptualized the relationship between folklore research, the Nationalitätenfrage, and the Austrian imperial structure in increasingly divergent ways. For Krauss, Volkskunde's ultimate objective was the discovery of a science of nationality, a theory or theories by which to explain how and why nations come into being. The intended result was to in a sense "denaturalize" nationalism, to expose its social, political, economic, and psychological roots. Kaindl, on the other hand, sought to reposition the nation within a larger, more complex constellation of political affiliations, to sanctify national identity through its re-framing as an indispensable mode of belonging.

First, Krauss' understanding of the political significance of Volkskunde. At the heart of his critique of academic historicism lay an attempt to combat the essentializing and racialist narratives this mode of history tended to produce. In his introduction to a 1902 review of recent folklore literature, Krauss wrote the following:

All understandings of man as a natural phenomenon which organize themselves according to race are based on theories which, though they sound good, remain utterly useless for our evolutionary-historical mode of inquiry; for the objects of our research are the acquired and habituated characteristics of man as a social being (Gesellschaftswesen), or, more precisely stated, society as intellectual operations management (geistige Betriebsleitung) ([14], p. 174). 
His turn to the people as a product of material society, as a "natural phenomenon," was intended to undercut systems of racial classification. By treating "the people" as a real, existing, and socially complex group, rather than the manifestation of some kind of transcendent racial ideal, Krauss hoped to contest the bloated claims of not just South Slav nationalists, but also the German ethnic nationalists who threatened to render him nation-less (cf. [9], pp. 76-77). "Ethnologists," he stridently maintained, "are neither salon entertainers, nor aesthetes, nor moral censors [Sittenrichter], but rather those who seek to comprehend mores [Sittenergründer]" ([32], p. IX). The "purpose and objective" of Volkskunde was, he stated in this same piece, to learn how to remove one's "Kulturbrille," one's "cultural lenses" ([32], p. IX).

Krauss did not, to be sure, view the subject of nationalism from the same relativist-constructivist perspective to which the past thirty or so years have given rise. Unlike the work of Benedict Anderson, Ernest Gellner, and other widely influential contemporary theorists of nationalism, Krauss's critical interventions addressed primarily the theoretical comparability and equality of cultural formations, rather than the discursive mechanisms or structural pressures which produce forms of group self-identification. Furthermore, while critical of both Pan-Slavism and Pan-Germanism, Krauss clearly felt a special attachment to the increasingly antiquated political vision of mid-19th-century German liberalism, serving as secretary of the liberal-assimilationist Israelitische Allianz in Vienna from 1891 to 1901 ([9], p. 75). That said, it would be difficult to deny the groundbreaking quality of Krauss's work. Krauss enjoyed the close acquaintanceship of several of the leading minds of the time, including Franz Boas - who authored the foreword to the first volume of Krauss's scholarly yearbook Anthropophyteia (1903-1912) — and Sigmund Freud, who cited Krauss's work on folk erotica in his The Interpretation of Dreams (1899) ([33], pp. V-VI; [34]). An at least notional, if in reality somewhat compromised, commitment to the scientific value of cultural relativism, coupled with a firm rejection of prevailing historical-evolutionary and biological-racial explanatory frameworks, placed Krauss's work squarely on the forefront of the field.

Kaindl, on the other hand, wished to create an intellectual and political space for the legitimation of national identities, particularly those less rooted in a historical political tradition. His goal was not to disenchant notions of national belonging, but rather, in the early stage of his career, to restructure and recast Austria's constituent peoples in a new, unifying conceptual geography. In the final chapter of his abovementioned book, Kaindl took up the issue of folkloristic pedagogy, specifically the question of how to most effectively convey to students folklore's "patriotic and cosmopolitan significance" ([2], p. 46). What he recommended was a multistep process of identity formation, one in which students begin with the customs of their local community and continually draw wider connections, first to their "homeland," then to the various cultures of their "fatherland," then to the customs of remote continents. He provided the following as an example of this desired progression:

If, for example, the Johannisfeuer or the Yule log is being discussed, this will interest any student who has ever sat by a solstice fire (Sonnwendfeuer) or next to a lit Christmas tree. With great interest he will hear, for example, that the Hutsels in the Carpathian forests light a "living fire" on the 24th of December...and the so-called Feuerweihe in Rauris and Bucheben in Salzburg during solstice festivals presents us with something similar...After 
these observations, students will find it interesting to note that a New Fire Ceremony also takes place at the beginning of winter among the North American Indians ([2], p. 140).

Ideally, the instructor would begin with a common, familiar custom, then proceed to situate this custom in a constellation of national and international cultural practices, in this case, the traditional ceremonial fires of Carpathian Hutsels, Salzburgers, and North American Indians. He then offers an additional example, this time connecting Ruthenian customs to those of ancient Egypt:

When, for example, the teacher tells his students about the veneration of certain animals in ancient Egypt, he should not miss the opportunity to allude to the fact that still today specific animals, such as the stork, the swallow, and also the snake and weasel enjoy a certain degree of veneration or arouse popular superstitious fears. Just as the Apis was venerated in Egypt, the Ruthenians, for example, celebrate an "Ox Festival Day" during which these animals are not to be put to work...observations such as these erect strong bridges between then and now, the foreign and the familiar...([2], p. 141).

Yet again, we find a concerted effort on the part of Kaindl to bridge provinces, nations, empires and civilizations in a cohesive, unifying conceptual field. The student begins with what he knows, and slowly fits these puzzle pieces of local knowledge into a unified picture of the world and its history.

Though it may appear to be little more than a convenient pedagogical trick, Kaindl's method of instruction aimed to have an influence on much more than the Gymnasium classroom. Integrating lessons of this sort into Austrian curricula would not only enrich students' general humanistic education, but also offer tangible political benefits, both for the (vaguely defined) Heimat ("Homeland") as well as for the Austrian state [35]. "The high value of Volkskunde for the revival of love for the homeland and the fatherland is," Kaindl argued in the same text, "indisputable" ([2], p. 142). Unlike academic history, whose romantic, insular narratives increasingly posited nationality as the sole form of political affiliation, ethnography would, in Kaindl's model, treat the nation as one form, one layer, of belonging. Through an individual's identification with the nation, loyalty to the supranational empire would not only be preserved, but would, in fact, be reinforced.

What Kaindl promoted, then, was a new, multilayered order of belonging, one in which Heimat, nation, fatherland, and world were linked in a logical progression. To a certain extent, this sort of thinking did indeed take root in Austria-Hungary, though not exactly in the politically stabilizing manner he hoped it would. Between "Heimat" and "world," new geopolitical concepts were around this time beginning to capture the imaginations of both the general public and the academe, most notably, in the context of Austria, Pan-Germanism, Pan-Slavism, and Hungarian Turanism. Scholars and politicians alike increasingly began to think in terms larger and grander than the nation, but many of these new geopolitical landscapes constituted little more than global projections of national interests and nationalist projects. Seeking, like Kaindl, "a principle deeper than nationality," many ethnographers laid claim to a primitive, historical inheritance, a primal essence that inflated, rather than deflated, the national pretensions of the empire's different peoples. That Kaindl himself turned to Pan-German politics after the collapse of the empire points to Volkskunde's unique capacity to both relativize and sacralize national particularism [36]. The attempt to formulate a social category more basic than nationality ended up producing new, more outward-looking forms of nationalism. 
Ultimately, both Krauss's quest for a science of nationality and Kaindl's struggle to wed ethnic nationalism to a kind of pro-imperial politics failed to achieve their desired effect [37]. Most of Krauss's scholarly and literary publications after 1890 received only a cool reception from reviewers, and in $1897 \mathrm{Am} \mathrm{Ur}$-Quell, long struggling financially, printed its final issue. In the years leading up to World War One, Krauss edited a scholarly yearbook for "folkloristic research on the evolution of sexual morality"; this journal, his most professionally influential and financially successful, came to an abrupt end when, in 1913, a Berlin court charged him with marketing pornography. Following his trial and the confiscation of his work by state authorities, Krauss slowly retreated from the academic stage. He lived out the rest of his life in Vienna, publishing short articles in minor journals and occasionally discoursing on the state of the field with friends and colleagues; he died in 1938, a few months after Nazi troops entered Austria.

Kaindl's career was only marginally more successful. Already by the mid-1900s, Kaindl had begun to change tack and head in a more openly legitimationist direction; he continued to emphasize the use of folkloristic and other cultural historical techniques in his work, but this interest in a kind of comparative ethnology, whether genuine or purely rhetorical, gave way to a scholarly program explicitly aimed at establishing the unity and cultural superiority of the Bukovina and Galicia's German-speaking diaspora. These efforts were regarded with skepticism by both the Schönerianer, who viewed the Bukovina as irrecoverably corrupted by "non-German" influences, and Christian Socials, who accused Kaindl of fraternizing with the region's Jewish community ([17], p. 139). And while Kaindl, unlike Krauss, did manage to find a place in Austrian academia, his idiosyncratic brand of politics - neither typically Pan-German nor Catholic conservative-brought him, following the end of monarchy, into increasing conflict with these two right-wing factions [38]. He was a committed proponent of Anschluss, yet clung to the increasingly unpopular idea of a "Donauraum," a Central European confederation of small states to be attached to the German Reich.

It would, however, be a mistake to dismiss these "social democrats of scholarship" as curious, though ultimately inconsequential, anomalies. In tracing the conversation between these figures, we encounter another story of the late empire, a new and more nuanced way of understanding its intellectual dynamics. In the context of East-Central Europe, the social sciences-particularly history - have traditionally been regarded as little more than the handmaidens of nationalism. A picture of mindless, un-self-critical scholarly chauvinism, first painted by Hans Kohn and frequently reproduced in the decades since, continues to guide many investigations into the intellectual history of this region, despite its obvious inability to adequately account for the large body of groundbreaking, counter-paradigmatic literature to which this region gave rise [39]. As we have seen, alongside, and to some extent within, academic history there emerged formidable anti-establishment currents, theoretical frameworks that explicitly challenged the political claims of the newly apotheosized nation-state of the late 19 th century, in our case early folkloristics. In fact, one could easily make the argument that it was in imperial Austria that some of the earliest examples of an anti-essentialist and consciously anti-Eurocentric science of nationality first emerged [40].

These countercurrents, second, arose out of a convergence of disparate political interests. Just as ethnic Germans, facing a rising tide of Czech nationalist agitation, entered into a strategic alliance with a certain segment of Prague's Jewish community during the final decades of the 19th century, in the sphere of academic life there emerged a number of relationships defined by intellectual co-dependency, 
many of them between scholars sharing seemingly little in common ([3], esp. pp. 162-63). As we have seen, both Slavonian Jews and "Carpathian Germans" hitched their visions for political reform to a particular brand of folklore research. Pivoting away from the academic establishment and turning to the study of folk customs was not simply and exclusively a reactionary phenomenon; in reality, this emerging discipline, at first marginal, then increasingly prestigious, became the intellectual mercenary of various forms of both pro- and anti-Habsburgism, progressive politics and reactionary nationalism.

In addition to complicating certain overly simplistic-perhaps, one might even argue, orientalist - characterizations of East Central European intellectual history and re-orienting our discussions of minority activism, the case study presented above compels us, third and finally, to reconsider the geography of Austrian scholarship during the late 19th and early 20th centuries, particularly the relationship between the empire's large and increasingly linguistically homogenous urban centers and its more ethnolinguistically heterogeneous peripheries. As the late historian Bernd Weiler noted more than a decade ago, contemporary commenters on the nature of the Dual Monarchy generally viewed their subject from one of two perspectives. Some, primarily those writing to legitimize state policies, assumed a kind of internal coherence to the empire, a "unity-within-diversity" [41]. For them, the monarchy was the expression of universal truths, a "harmonious cohabitation" of distinct, though fundamentally complementary, peoples and cultures [41]. Other, more relativistically minded thinkers - such as Ludwig Gumplowicz, Eugen Ehrlich, Bronisław Malinowski and Karl Mannheim, to cite Weiler's examples-understood the monarchy's unity as a "superficial phenomenon," instead interpreting the state as a kind of "diversity-within-unity" [41]. What united members of this second camp, Weiler observes, was neither language nor politics, but rather their place of intellectual maturation. It was in multinational borderlands, where partially naturalized members of dominant communities "constantly mov[ed] between linguistic, ethnic, and religious boundaries," that the four scholars listed above acquired the relativistic habits of mind and "ethnographic sensibility" which distinguished their work [41].

In light of the foregoing analysis of Krauss and Kaindl's work, we might, however, consider further refining Weiler's geographic paradigm. It would appear that this ethnographic sensibility, while cultivated in specific, highly localized sites, crystallized into distinct discourses, such as folkloristics and sociology, as a result of momentary, although in many cases highly significant, alliances and exchanges between marginal figures. The theories and concepts which came to define Austrian Kulturwissenschaft, both at home and abroad, emerged out of mutual dependencies between those thinkers who found themselves, like Krauss and Kaindl, in some sense endangered by a romantic, historicist vision of political development [42]. As both the pages of academic journals and the record of the Austrian Imperial Council reveal, a distinctive and, in a certain sense politically disruptive, new way of thinking took root during the final decade of the $19^{\text {th }}$ century, one in which the present threatened to displace the past as the primary source of political legitimacy and the historical question of political formation began to give way to the sociological question of cultural differentiation [43].

\section{Conflicts of Interest}

The author declares no conflict of interest. 


\section{References and Notes}

1. Friedrich Salomon Krauss. "Ethnologische Mitteilungen aus Ungarn." Am Ur-Quell. Monatsschrift für Volkskunde 4 (1893): 151-52. Geben wir uns keiner Selbsttäuschung hin, sondern gestehen wir es offen und unumwunden ein, daß Volkskunde noch gegenwärtig in Europa eine der unpopulärsten und am wenigsten beachteten Wissenschaften ist. Die Ursache ist leicht herauszufinden...[Volkskunde] ist trotz der Mannigfaltigkeit ihrer Stoffe, die unmittelbar dem Leben entnommen sind, eine gar trockene Disziplin, zumal da ihr Vorwurf immer und immer nur das, Volk ist, das noch vor wenigen Jahrzehnten den privilegierten Klassen gegenüber nur für eine Null angesehen wurde. Die Volksforscher sind so zu sagen die Sozialdemokraten in der Wissenschaft. Sie sind die Neuerer, die Umstürzler, die Zweifler, die dilettantischen Vielwisser, die Verächter der schulmäßigen, „historischen Kritik, “sie sind Naturwissenschaftler, die sich nicht entblöden, den Herrn der Schöpfung, den Menschen, so zu betrachten, wie man sonst nur die Tierwelt in ihrem Leben und Treiben beobachtet und beschreibt.

2. Raimund Friedrich Kaindl. Die Volkskunde: Ihre Bedeutung, ihre Ziele, und ihre Methode. Leipzig and Wien: Franz Deuticke, 1903.

3. Gary Cohen. Politics of Ethnic Survival: Germans in Prague, 1861-1914. West Lafayette: Purdue University Press, 2006.

4. Ludwig von Katona. "Ethnographie, Ethnologie, und Folklore. Auszug aus einem Vortrage, gehalten in der Sitzung der Gesellschaft für die Völkerkunde Ungarns am 11. Januar 1890.” Ethnologische Mitteilungen aus Ungarn 2 (1892): 43-51. Es ist eine in der Geschichte der Wissenschaft sich oftmals wiederholende, sozusagen reguläre Erscheinung...dass neue Wissenschaftszweige gezwungen sind eine Zeit lang um ihre Existenz zu kämpfen.

5. Anton Hermann. "Die ethnographische Gestaltung der Bevölkerung Ungarns." Ethnologische Mitteilungen aus Ungarn 5 (1896): 1-6. Unsere Staatsmänner zeigen im Allgemeinen noch wenig Sinn für die politische Wichtigkeit der Ethnographie.

6. See Miklós Bánffy. The Transylvanian Trilogy: They Were Divided. London: Arcadia, 2011, vol. 2. "He saw the professors of history, who thought only of the revolutionary struggle against the Habsburg domination and who denigrated those who would have encouraged the Hungarian people to self-knowledge and hard work, with the result that the minds of the young had been filled only with illusory ideals and chauvinistic slogans."

7. For more on the details of Krauss's biography, as well as his sense of national identity, see Christoph Daxelmüller. "Friedrich Salomo Krauss." In Völkische Wissenschaft. Gestalten und Tendenzen der deutschen und österreichischen Volkskunde in der ersten Hälfte des 20. Jahrhunderts. Edited by Wolfgang Jacobeit, Hannjost Lixfeld and Olaf Bockhorn. Wien: Böhlau, 1984, pp. 463-76.

8. Friedrich S. Krauss. Sitte und Brauch der Südslaven. Wien: Alfred Hölder, 1885. Der Unterschied zwischen mir und ihnen "meinen Vorgängern, den südslavischen Historikern von Profession" besteht nur darin, dass sie gewöhnlich in vollem Glauben die Vergangenheit darstellen, als wären sie überall dabei gewesen, während ich von Haus aus in diesen Dingen ein Ketzer bin. Die ältere Geschichte der Südslaven ist nicht meine Geschichte. 
9. Cited in Raymond L. Burt. Friedrich Salomo Krauss (1859-1938): Selbstzeugnisse und Materialien zur Biobibliographie des Volkskundlers, Literaten und Sexualforschers mit einem Nachlassverzeichnis. Wien: Verlag der Österreichischen Akademie der Wissenschaften, 1990. Erklärt man, z.B. die allgemeine Übereinstimmung gesellschaftlicher Einrichtungen und Anschauungen der Menschheit aus seiner einheitlichen Überlieferung oder Blutverwandschaft oder gemeinsamen politischen Geschichte, so bleibt man an Scheinbeweisen und Vermutungen zu kleben und erklärt gar nichts sicher. Begreift man dagegen die gleichartige geistige Veranlagung des Menschen, wo immer er auftritt und sein Fähigkeit, sich der Umgebung notwendigerweise anzuschmiegen, so entfällt von selber jeder...Schwierigkeit, das Vorhandene und Gewordene zu verstehen.

10. For more on the research agenda of the Anthropologische Gesellschaft, see Karl Pusman. "Die 'Wissenschaften vom Menschen' auf Wiener Boden (1870-1959): Die anthropologische Gesellschaft." In Wien und die anthropologischen Disziplinen im Fokus von Wissenschaftsgeschichte, Wissenschafts- und Verdrängungspolitik. Münster: LIT Verlag, 2008.

11. Friedrich S. Krauss. Volksglaube und religiöser Brauch der Südslaven. Münster i.W.: Aschendorff, 1890.

12. Friedrich S. Krauss. Böhmische Korallen aus der Götterwelt. Wien: Gebrüder Rubinstein, 1893, pp. 88-89.

13. Gregor Krek. Einleitung in die Slavische Literaturgeschichte. Graz: Verlag v. Leuschner u. Lubensky, 1887.

14. Friedrich S. Krauss. Die Volkskunde in den Jahren 1897-1902: Berichte über Neuerscheinungen. Erlangen: Ferlag v. Fr. Junge, 1903.

15. Friedrich S. Krauss. Die vereinigten Königreiche Kroatien und Slavonien. Wien: Karl Graeser, 1889.

16. Alexander Blase. Raimund Friedrich Kaindl (1866-1930). Leben und Werk. Wiesbaden: O. Harrassowitz, 1962, pp. 19, 31.

17. Alexander Pinwinkler. "Raimund Friedrich Kaindl: Geschichte und Volkskunde im Spannungsfeld zwischen Wissenschft und Politik." In Österreichische Historiker, 1900-1945. Edited by Karel Hruza. Wien: Böhlau Verlag, 2008, p. 131.

18. Karl Weinhold. "Was soll die Volskunde leisten?" Zeitschrift für Völkerpsychologie und Sprachwissenschaft 20 (1890): 1-5.

19. Albrecht Dietrich. Über Wesen und Ziele der Volkskunde. Leipzig: B.G. Teubner, 1902.

20. Eduard Hoffmann-Krayer. Die Volkskunde als Wissenschaft. Zürich: F. Amberger Verlag, 1902.

21. Adolf Strack. "Volkskunde." Hessische Blätter für Volkskunde 2 (1902), 149-56.

22. "Historicism" as a term is difficult to define, and has been used at different times to refer to a number of concepts. In the 19th century, particularly in history, philology and related fields, "historicism" referred to the belief that all ideas and actions should be understood as context-dependent, historically specific phenomena. Furthermore, it tended to emphasis the organic growth and development of national groups. German historical science laid the foundation for the broader European turn toward historicism. For a historical overview of German historicism, see Georg G. Iggers. The German Conception of History: The National Tradition of Historical Thought from Herder to the Present. Middletown: Wesleyan University Press, 1983. 
23. For a comparative analysis of several important East Central European historians from this period, see Monika Baár. Historians and Nationalism. East Central Europe in the Nineteenth-Century. Oxford: Oxford University Press, 2010.

24. By the end of the 19th century, historicist frameworks were deeply entrenched in the academic and public culture of both Western and Eastern Europe. For a glimpse into the complex interplay between historical preservation and discourses of civilizational advancement in Austrian Galicia, see Nathaniel Wood. Becoming Metropolitan: Urban Selfhood and the Making of Modern Krakow. Dekalb: Northern Illinois University Press, 2010.

25. For historical research into the process of popular historicization in Germany, see John Toews. Becoming Historical: Cultural Reformation and Public Memory in Early Nineteenth-Century Berlin. Cambridge: Cambridge University Press, 2004.

26. Otto Bauer. The Question of Nationalities and Social Democracy. Translated by Joseph O’Donnell. Minneapolis: University of Minnesota Press, 2000.

27. Otto Bauer. Geschichte Österreichs: eine Anleitung zum Studium der österreichischen Geschichte und Politik. Wien: R. Danneberg, 1913. Wir kennen die österreichische Geschichte aus der Volksschule. Sie erzählt uns von Fürsten, Staatsmänner und Feldherren, von Heiraten, Erbverträge und Schlachten. Das Schicksal des Staates und der Völker erscheint abhängig von der Begabung, dem guten Willen und dem Glück der einzelnen Herrscher.

28. Fritz Martin Mayer. Geschichte Österreichs, mit besonderer Rücksicht auf das Culturleben, 2nd ed. Wien and Leipzig: Wilhelm Braumüller, 1900.

29. Raimund Friedrich Kaindl. Geschichte und Kulturleben Deutschösterreichs: Auf Grundlage der “Geschichte Österreichs” von Franz Martin Mayer. Wien: Braumüller, 1929.

30. Josef Helfert. Über Nationalgeschichte und den gegenwärtigen Stand ihrer Pflege in Oesterreich. Prag: Calve'schen Buchhandlung, 1853.

31. Hans von Voltelini. "Die österreichische Reichsgeschichte, ihre Aufgaben und Ziele." Deutsche Geschichtsblätter 2 (1901): 97-108.

32. Friedrich S. Krauss. "Vorwort." Anthropophyteia: Jahrbücher für Folkloristische Erhebungen und Forschungen zur Entwicklungsgeschichte der geschlechtlichen Moral 1 (1904): VII-XXI.

33. Franz Boas. "Vorwort." Anthropophyteia: Jahrbücher für Folkloristische Erhebungen und Forschungen zur Entwicklungsgeschichte der geschlechtlichen Moral 1 (1904): V-VI.

34. Johannes Reichmeyr. "Friedrich Salomon Krauss and Sigmund Freud-Begegnung unorthodoxer Gelehrter." Luzifer Amor 1 (1988): 133-55.

35. Austria is generally referred to by Kaindl as the Vaterland. Heimat refers primarily, it seems, to a province or smaller region (Salzburg or the Bukovina, for example).

36. Kaindl became a leading voice in German minority rights activism in East Central Europe following the Paris Treaties. He turned in this period to a program of "großdeutsche Geschichtsschreibung," and called on his fellow Reich and Austrian Germans to establish a German-dominated Mitteleuropa. See R. F. Kaindl. Österreich, Preußen, Deutschland: Deutsche Geschichte in großdeutscher Beleuchtung. Wien: Braumüller, 1926.

37. Natasha Wheatley, a post-doctoral research fellow at the University of Sydney, is currently working on the notion of "historical rights" as it undergirded claims to national sovereignty in East Central Europe.

38. Kaindl's trajectory is not unique is this regard. WWI re-directed and often radicalized certain pre-war methodological tendencies in the social and cultural sciences. For more on this topic, see Andre 
Gingrich. "Krise des Weltkriegs und Transformation eines Wissenschaftsfeldes: Ethnographie und Anthropologie in Österreich-Ungarn und Deutschland bis 1914/18 und danach." In Krise und Transformation: Beiträge des Internationalen Symposiums 2010 an der Österreichischen Akademie der Wissenschaften. Edited by Sigrid Degler-Jalkotzy and Arnold Suppan. Wien: Verlag OEAW, 2010, pp. 209-25.

39. For a classic, and still very influential, interpretation of the region's supposed pathologies, see Hans Kohn. The Idea of Nationalism: A Study in its Origins and Background. New York: MacMillan, 1944. Recently, there have been attempts to "normalize" East-Central European historiography and to rescue its political legacy, including Monika Baár's abovementioned book. This newer account does not, however, pay sufficient attention to the uniqueness of the intellectual history of this region, instead stressing the normality of these fields of study vis-à-vis Western European disciplines.

40. A conference, recently held at the Institut für Ost- und Südeuropaforschung in Regensburg, was dedicated to exactly this question of East Central Europe's impact on the global history of the social sciences. The conference's organizers attribute the region's unique contributions to social science to its "non-normative status within the modern world." See Rachel Trode, and Eszter Varsa. "Tagungsbericht: Epistemologies of In-Betweenness: East-Central Europe and the World History of Social Science, 1890-1945." Available online: http://www.hsozkult.de/ conferencereport/id/tagungsberichte-6117 (accessed on 14 October 2015).

41. Bernd Weiler. "E Pluribus Unum? The Kakanian Intellectual and the Question of Cultural Pluralism." Paper presented at The Contours of Legitimacy in Central Europe: New Approaches in Graduate Studies, St. Anthony's College, Oxford, UK, 24-26 May 2002.

42. Karl Acham argues that, in the decades before the Jahrhundertwende, it was Austrian sociology that enjoyed particular renown in Western Europe and North America. "Ludwig Gumplowicz und der Beginn der soziologische Konflikttheorie im Österreich der Jahrhundertwende." In Kulturwissenschaften im Vielvölkerstaat: zur Geschichte der Ethnologie und verwandter Gebiete in Österreich, ca. 1780 bis 1918 = L'anthropologie et l'état pluri-culturel: le cas de l'Autriche, de 1780 à 1918 environ. Edited by Britta Rupp-Eisenreich and Justin Stagl. Wien: Böhlau, 1995.

43. See, for example, the 1892 debate in the Abgeordnetenhaus surrounding Tomas Masaryk's proposed introduction of a mandatory sociology course for students of law in Bohemia. "106 Sitzung der XI Session am 29. Jänner 1892.” In Stenographische Protokolle über die Sitzungen des Hauses der Abgeordneten. Wien: Kaiserlich-königliche Hof- und Staatsdruckerei, 1892, pp. 4845-57. Masayrk, in defending his proposal, declared to his fellow parliamentarians: Der Staat wird Gesellschaft, sagen wir kurz, er wird social-man muss dabei nicht an die Sozialdemokratie denken - und es ist dann begreiflich und naturgemäß, dass ich dieser Staat eine sociale Rechtsordnung gibt. Sie selbst, meine Herren, während ich mir so erlaube die moderne Auffassung des Staates vorzubringen, unwillkürlich an Österreich denken; hier ist die Vielheit der einzelnen Gebilde eine so große, dass der sociale Umwandlungsprocess darum so schwierig ist. Darum ist der sociale Staat das österreichische Problem und in diesem Bestande ist das österreichische Problem das Zeitproblem (emphasis added).

(C) 2015 by the author; licensee MDPI, Basel, Switzerland. This article is an open access article distributed under the terms and conditions of the Creative Commons Attribution license (http://creativecommons.org/licenses/by/4.0/). 